\title{
Development and field testing of an online instrument for measuring the real-time oxidative potential of ambient particulate matter based on dithiothreitol assay
}

Joseph V. Puthussery et al.

Correspondence to: Vishal Verma (vverma@illinois.edu)

The copyright of individual parts of the supplement might differ from the CC BY 4.0 License. 


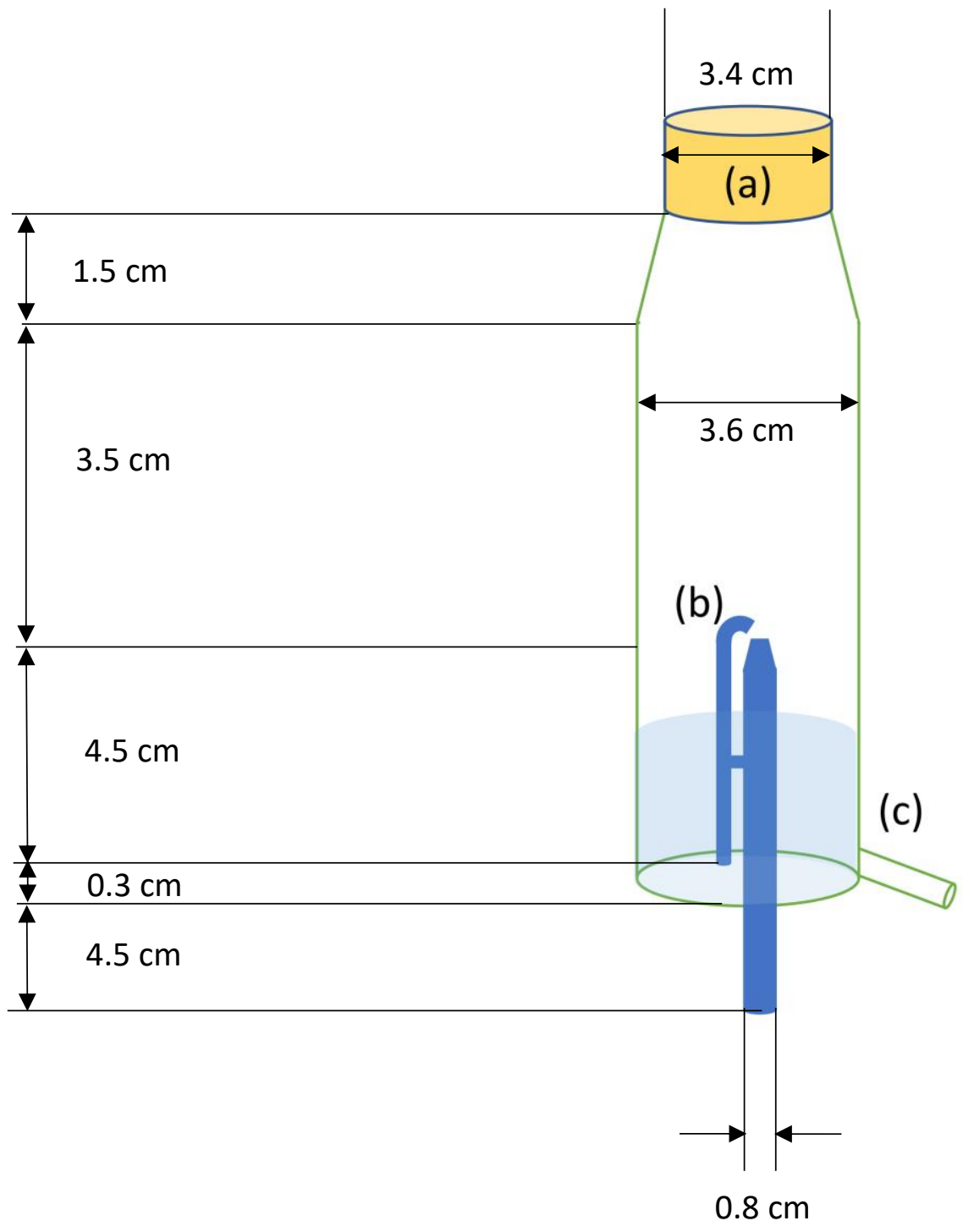

Figure S1: MC Dimensions (a) filter pack, (b) $0.3 \mathrm{~cm}$ internal diameter (ID) glass capillary tube and, (c) MC inlet/outlet tube ( $0.3 \mathrm{~cm}$ ID) connected to the automated DTT activity measurement system 


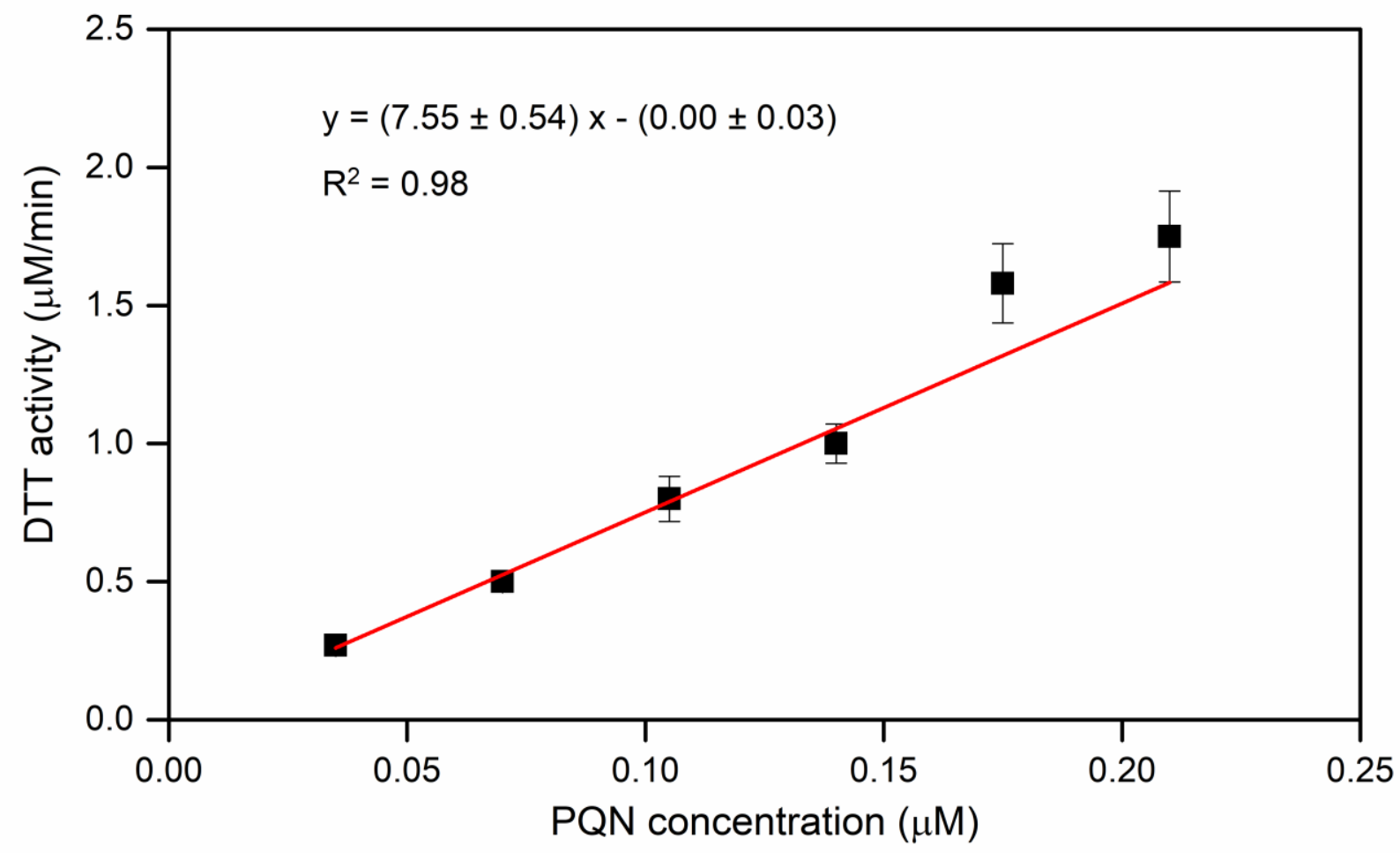

Figure S2: Calibration of the analytical (DTT activity determination) part of the online instrument using PQN standards. Error bars denote standard deviation $(1 \sigma)$ of triplicate measurement, and $\mathrm{PQN}$ concentration shown on $\mathrm{X}$-axis is the concentration inside the reaction vial. 


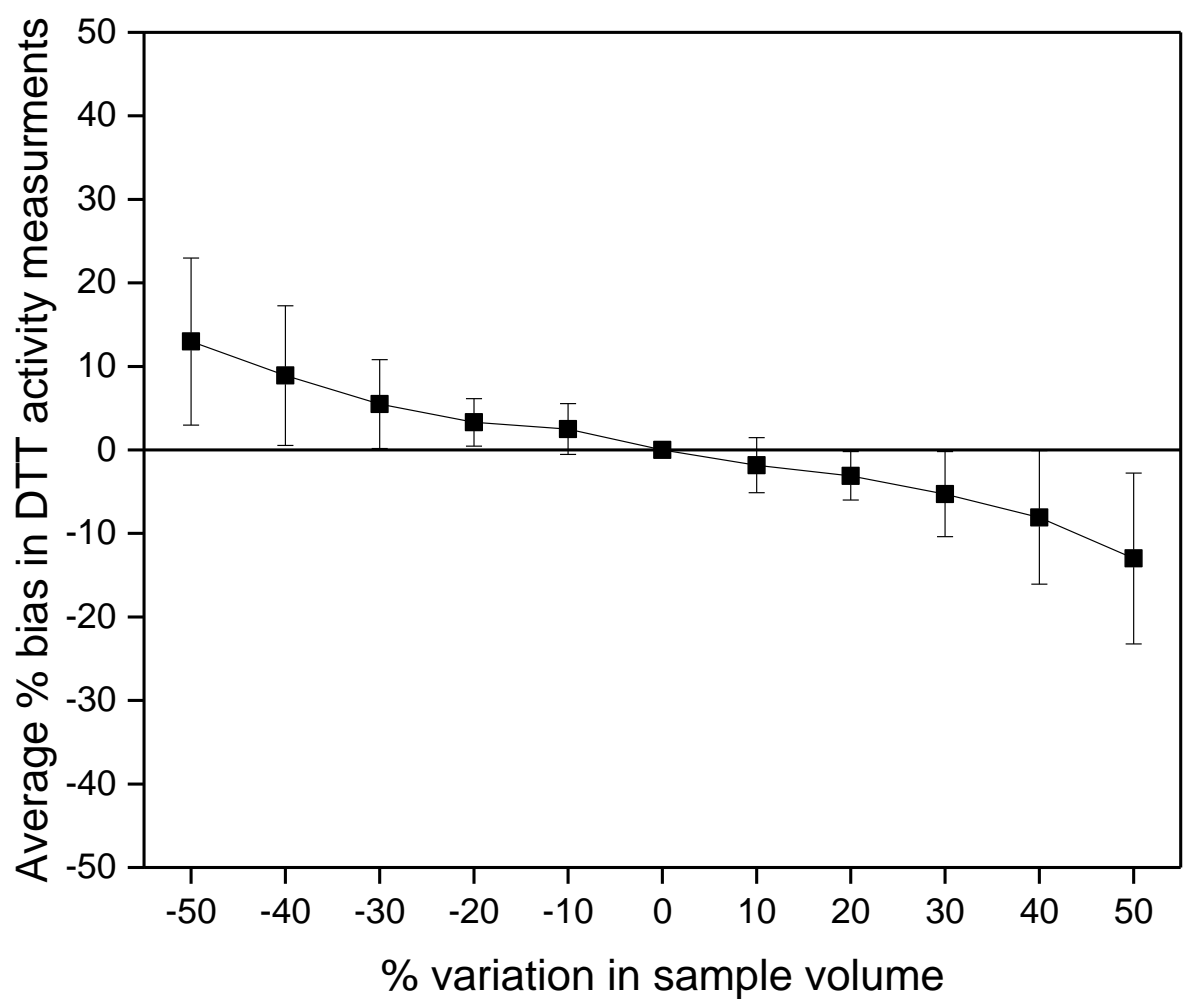

Figure S3. Effect of variation in the sample volume obtained from MC on the bias in DTT activity measurements. The data shown here is obtained from four different $\mathrm{PM}_{2.5}$ filters extracted in water. The error bars denote standard deviation $(1 \sigma)$ from the average bias.

The bias in the measured DTT activities due to change in the sample volume was determined as below:

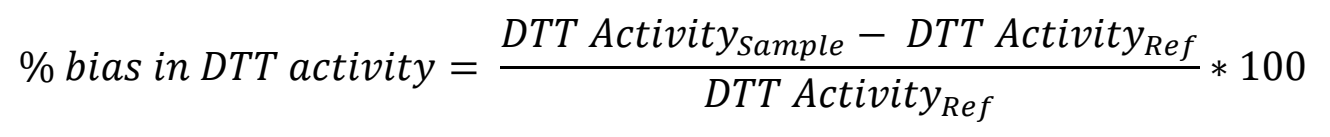

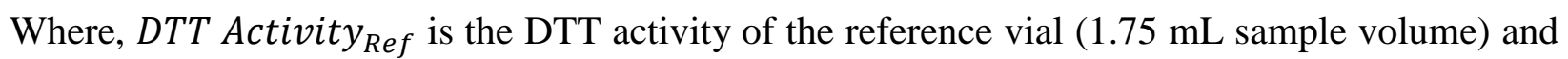

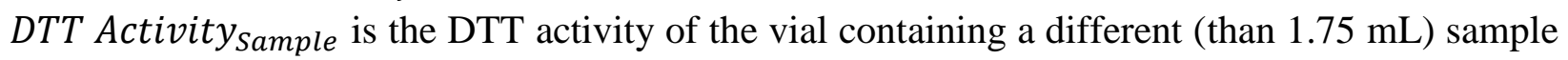
volume.

And, percentage variation in the sample volume is calculated as:

$$
\% \text { variation in sample volume }=\frac{\text { Volume }_{\text {Sample }}-\text { Volume }_{\text {Ref }}}{\text { Volume }_{\text {Ref }}} * 100
$$

Where, Volume $_{\text {Ref }}=1.75 \mathrm{~mL}$ and Volume Sample varies from $0.875 \mathrm{~mL}$ to $2.625 \mathrm{~mL}$ 


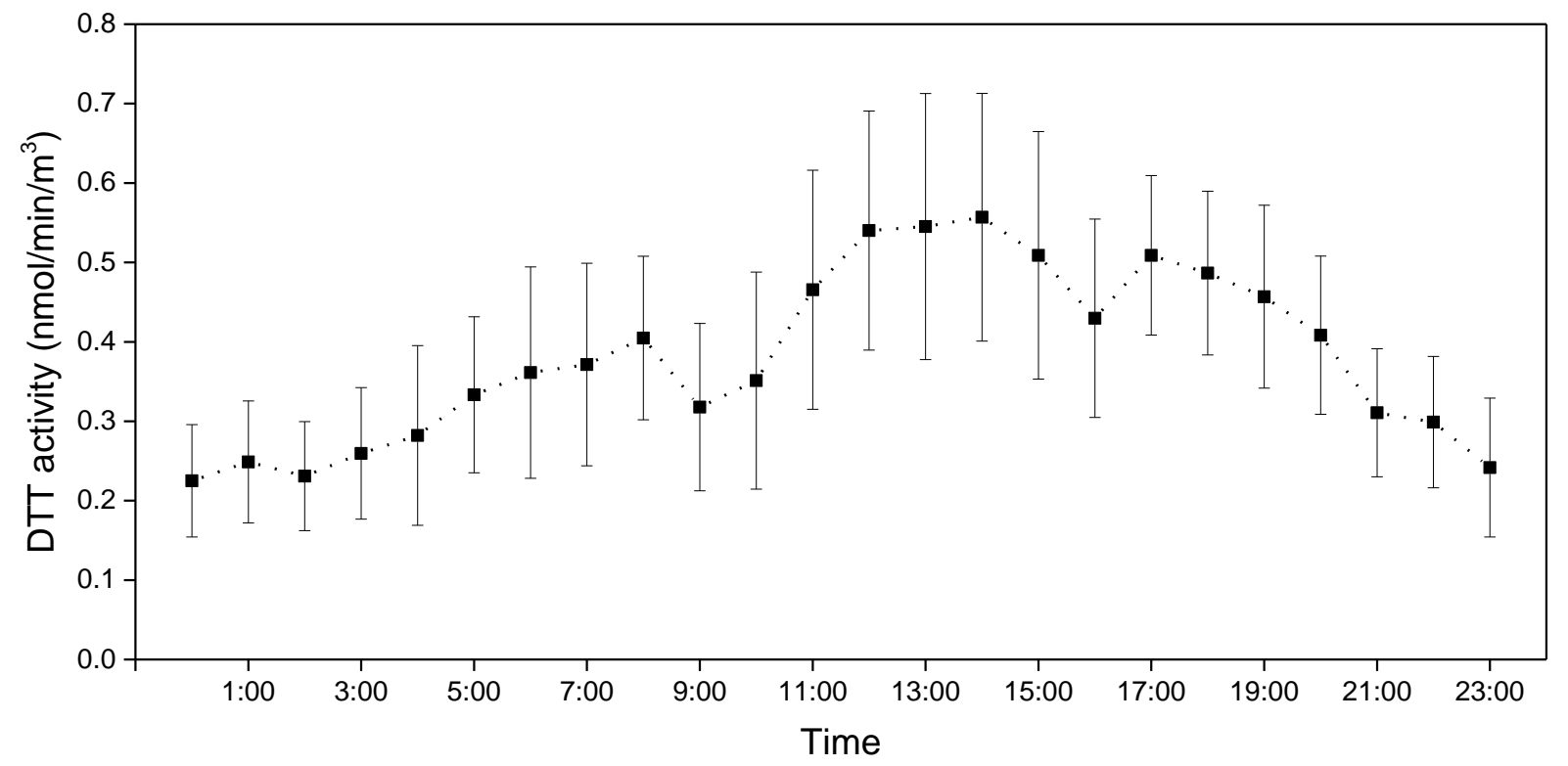

Figure S4: Diurnal profile of the ambient $\mathrm{PM}_{2.5}$ DTT activity measured at the sampling site during time-segregated sampling (August 4-16, 2017). Weekends were not included in plotting this profile.

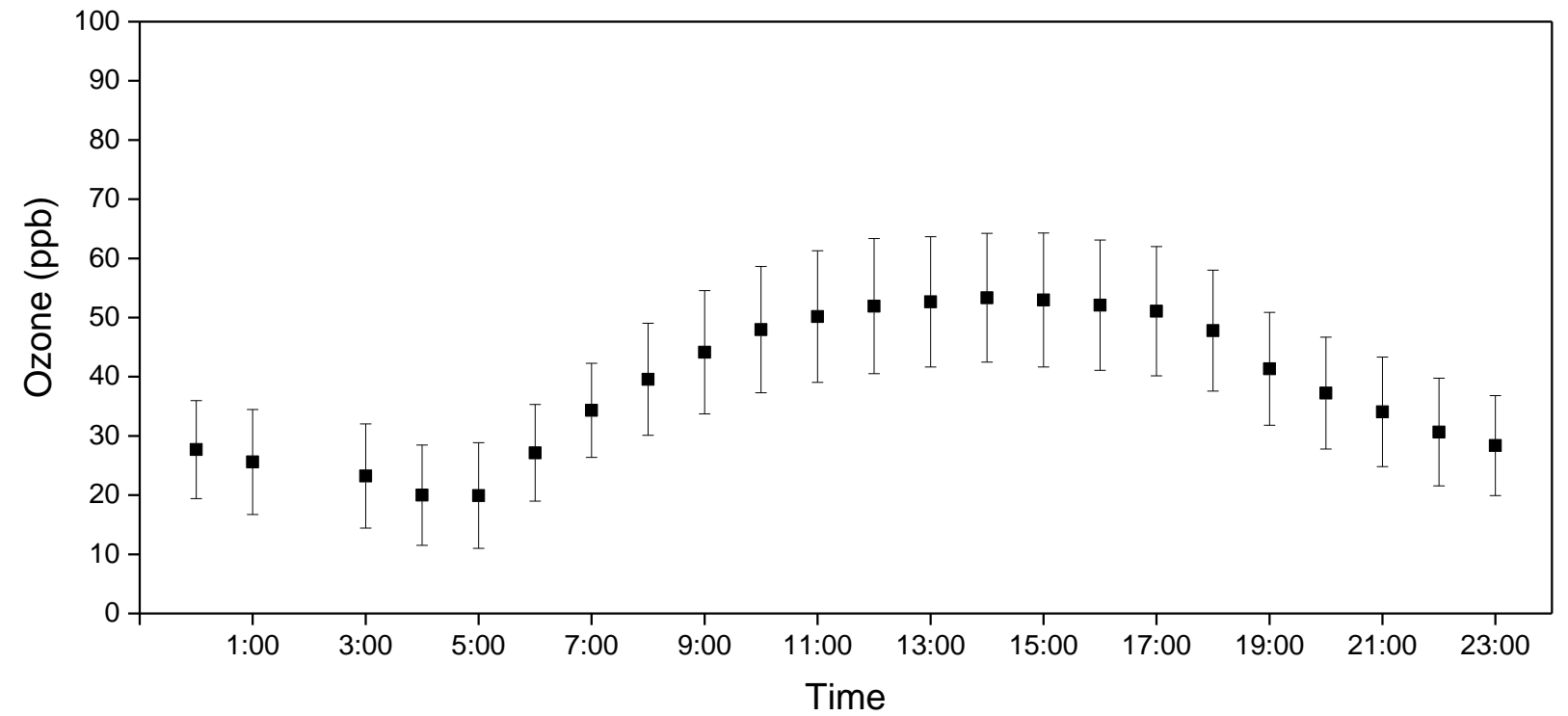

Figure S5: Diurnal trend in the hourly averaged ozone concentration (June 1-June 30, 2017) measured at Bondville (AirNow-Tech, 2017). 


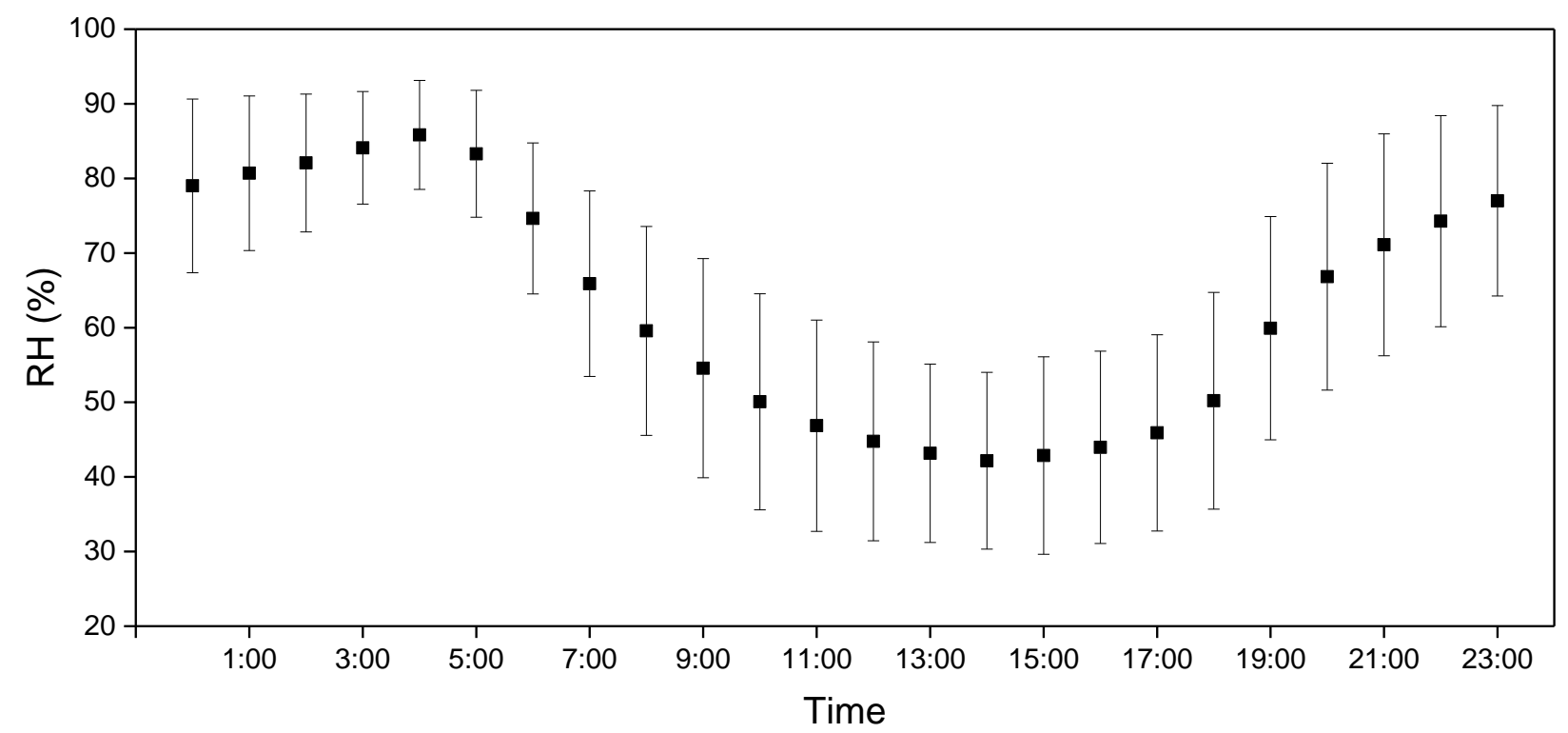

Figure S6: Diurnal trend in the hourly averaged ambient RH (June 1 - June 30, 2017) measured at Bondville (AirNow-Tech, 2017). 
Table S1: Details of sampling (e.g. dates, number of samples, additional remarks, etc.) for various experiments

\begin{tabular}{|c|c|c|c|}
\hline Experiment & $\begin{array}{l}\text { Sample ID/Number } \\
\text { of samples }\end{array}$ & Date & Remarks \\
\hline $\begin{array}{l}\text { Online versus offline } \\
\text { comparison } \\
\text { (a) Water extraction }\end{array}$ & $\begin{array}{l}\text { Total number of } \\
\text { filters: } 20\end{array}$ & $\begin{array}{l}1 / 24 / 2017 \\
1 / 25 / 2107 \\
1 / 30 / 2017 \\
2 / 1 / 2017 \\
2 / 2 / 2017 \\
2 / 5 / 2017 \\
2 / 6 / 2017 \\
2 / 7 / 2017 \\
2 / 8 / 2017 \\
2 / 9 / 2017 \\
2 / 10 / 2017 \\
2 / 11 / 2017 \\
2 / 13 / 2017 \\
2 / 14 / 2017 \\
\end{array}$ & $\begin{array}{l}\text { For offline DTT } \\
\text { activity analysis, PM } \\
\text { samples were } \\
\text { collected for a } \\
\text { duration of 1hour } \\
\text { parallel to the online } \\
\text { system. }\end{array}$ \\
\hline $\begin{array}{l}\text { Online versus offline } \\
\text { comparison } \\
\text { (b) Methanol } \\
\text { extraction }\end{array}$ & $\begin{array}{l}\text { Total number of } \\
\text { filters: } 16\end{array}$ & $\begin{array}{l}1 / 24 / 2017 \\
1 / 25 / 2017 \\
2 / 5 / 2017 \\
2 / 6 / 2017 \\
2 / 7 / 2017 \\
2 / 8 / 2017 \\
2 / 9 / 2017 \\
2 / 10 / 2017 \\
2 / 11 / 2017 \\
2 / 13 / 2017 \\
2 / 14 / 2017\end{array}$ & $\begin{array}{l}\text { For offline DTT } \\
\text { activity analysis, PM } \\
\text { samples were } \\
\text { collected for a } \\
\text { duration of 1hour } \\
\text { parallel to the online } \\
\text { system. }\end{array}$ \\
\hline $\begin{array}{l}\text { Time-segregated } \\
\text { sampling }\end{array}$ & $\begin{array}{l}\text { QS1, TS1 } \\
\text { QS2, TS2 } \\
\text { QS3, TS3 } \\
\text { QS4, TS4 }\end{array}$ & $\begin{array}{l}8 / 3 / 2017 \\
8 / 4 / 2017 \\
8 / 7 / 2017 \\
8 / 8 / 2017 \\
8 / 9 / 2017 \\
8 / 10 / 2017 \\
8 / 11 / 2017 \\
8 / 14 / 2017 \\
8 / 15 / 2017 \\
8 / 16 / 2017 \\
\end{array}$ & $\begin{array}{l}\text { Composite } \mathrm{PM}_{2.5} \\
\text { samples were } \\
\text { collected for } 10 \text { days } \\
\text { on each filter. Filter } \\
\text { sampling was not } \\
\text { conducted over the } \\
\text { weekends. }\end{array}$ \\
\hline
\end{tabular}


Table S2. Initial volume (i.e. at the start of the sampling run) of Milli-Q water added to the MC based on ambient RH

\begin{tabular}{|c|c|}
\hline Ambient RH (\%) & Volume of water $(\mathbf{m L})$ \\
\hline$<45$ & 16 \\
\hline $45-60$ & 12 \\
\hline $60-75$ & 10 \\
\hline $75-85$ & 5 \\
\hline$>85$ & 3 \\
\hline
\end{tabular}

These volumes of water were determined by numerous trials on $\mathrm{MC}$ in the field at extreme $\mathrm{RH}$ conditions.

References

AirNow-Tech: AirNow-Tech:Home, [online] Available from: http://airnowtech.org/ (Accessed 10 April 2018), 2017. 